\title{
PENERAPAN ALGORITHMA APRIORI UNTUK MENEMUKAN POLA PEMILIHAN KONSENTRASI STUDI MAHASISWA
}

\author{
Muhammad Jamaris $^{1)}$, Hadi Asnal ${ }^{1)}$, dan Yansyah Saputra Wijaya ${ }^{1)}$ \\ ${ }^{1}$ Program Studi Teknik Informatika, STMIK Amik Riau \\ Email : hadiasnal@stmik-amik-riau.ac.id
}

\begin{abstract}
Exploring information or new knowledge from existing data sets is an important point of the data mining process, such as a collection of course value data that has been stored, but its potential has not been raised to find new benefits. While on the other hand there is the problem of how to find the concentration of studies that are in accordance with the competencies of the students themselves. This study was conducted to find the concentration selection pattern, based on some of the best value data from the courses that have been taken using the Apriori Algorithma, where the rules in this method will be used to find the pattern in question. Using a minimum support value of $70 \%$ produces rules with 5 item sets, namely courses in logic and algorithms, system analysis, system design, web programming and software engineering. The pattern / rule produced can be a guide for students in choosing concentration.
\end{abstract}

Keywords: Data Mining, Apriori Algorithma, concentration.

\section{PENDAHULUAN}

Data yang tersimpan sangat beragam jenisnya, kadang kala ada data tertentu yang hanya dibiarkan begitu saja, sementara disisi lain ada bidang ilmu yang sebetulnya dapat membangkitkan potensi dari data-data tersebut yang biasa disebut dengan Data Mining.

STMIK Amik Riau merupakan sebuah perguruan tinggi komputer yang telah menerapkan kebijakan bahwa mahasiswa dalam tahap akhir diharuskan memilih konsentrasi Studi, ada 2 konsentrasi yang bisa dipilih oleh mahasiswa yaitu konsentrasi bisnis atau konsentrasi jaringan. Sedangkan masalah yang melatar belakangi penelitian ini adalah sering ragunya mahasiswa dalam menentukan konsentrasi studi. Selama ini dalam menentukan konsentrasi studi sebagian mahasiswa hanya ikut-ikutan teman padahal boleh jadi konsentrasi tersebut tidak cocok untuk mahasiswa yang bersangkutan, hal ini tentu kurang efektif dan mungkin saja berdampak tidak baik terhadap semangat belajar dan ilmu yang didapatkan.

Permasalahan yang telah dijelaskan diatas membuat tim peneliti tertarik untuk mencarikan solusi yaitu dengan memanfaatkan data-data nilai mahasiswa maka didapatkan pola pemilihan konsentrasi yang sesuai dengan potensi keahlian mahasiswa, sedangkan Algorithma Apriori dapat digunakan untuk menemukan hubungan atau sebab akibat (Han, Jiawei; Pei, Jian), dalam penelitian ini Association Rule digunakan untuk mengidentifikasi hubungan kesamaan antar item dan dilalui dengan tiga tahapan yaitu melakukan analisa pola, pembentukan aturan dan uji kekuatan rule yang terbentuk dari perhitungan ratio masing-masing rule. Dengan adanya penelitian ini diharapkan dapat membantu prodi maupun mahasiswa dalam menemukan pola pemilihan konsentrasi selama ini.

Data Mining merupakan proses yang mempekerjakan satu atau lebih teknik pembelajaran komputer (machine learning) untuk menganalisis dan mengekstraksi pengetahuan (knowledge) secara otomatis (Turban, Efraim \& Aronson, Jay E. 2001).

Data mining adalah serangkaian proses untuk menggali nilai tambah dari suatu kumpulan data berupa pengetahuan yang selama ini tidak diketauhui secara manual (Wirdah Choiriah, 2016).

Menurut Larose (2005) proses yang umumnya dilakukan oleh data mining antara lain: 
deskripsi, prediksi, estimasi, klasifikasi, clustering dan asosiasi. Algorithma apriori adalah teknik satu proses atau sistem yang digunakan untuk memproses data. Pertama, berbagai strategi disebut langkah untuk menemukan item yang sering. Kedua adalah menentukan aturan penambangan asosiasi. Metode dasar bisa dilakukan dalam dua tahap dalam proses rule asosiasi (Ependi, 2019).

\section{METODE PENELITIAN}

Dalam penelitian ini digunakan 6 tahapan, yang digambarkan sebagai berikut:

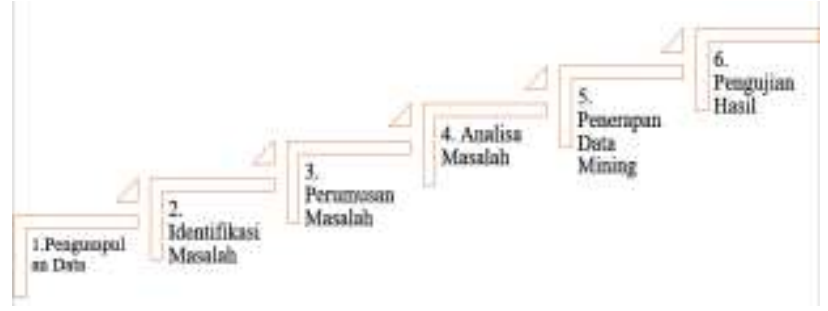

Gambar 1. Tahapan Kerja.

Berdasarkan gambar diatas, maka masing-masing tahapan tersebut dapat dijelaskan sebagai berikut:

\section{a. Pengumpulan Data}

Pada tahap ini akan dilakukan proses mengumpulkan dan mengukur informasi tentang variabel-variabel yang ditargetkan guna memperoleh informasi yang dibutuhkan dalam rangka mencapai tujuan penelitian. Data yang digunakan dalam penelitian ini adalah Data Sekunder yang mana data tersebut diperoleh langsung dari PDPT STMIK Amik Riau.

\section{b. Identifikasi Masalah}

Pada tahapan ini peneliti melakukan identifikasi masalah dengan menjelaskan apa masalah yang ditemukan dan bagaimana masalah tersebut diukur dan dihubungkan dengan prosedur penelitian.

\section{c. Perumusan Masalah}

Pada tahapan ini terbentuklah suatu pertanyaan yang akan dicarikan jawabannya melalui pengumpulan data dan identifikasi masalah yang merupakan tujuan dari penelitian.

\section{d. Analisa Masalah}

Setelah masalah berhasil dirumuskan, langkah selanjutnya adalah bagaimana menganalisa masalah yang ada pada dengan menggunakan data yang telah diperoleh sebelum nantinya diproses menggunakan data mining.

\section{e. Penerapan Data Mining}

Tahapan ini dapat dilakukan setelah analisa masalah diselesaikan, data yang tersedia diimplementasikan menggunakan data mining khususnya menggunakan algoritma apriori.

\section{f. Pengujian Hasil}

Setelah data berhasil diterapkan dengan menggunakan algoritma apriori, maka langkah selanjutnya adalah melakukan pengujian menggunakan aplikasi rapid miner.

\section{Data Penelitian}

Data yang digunakan dalam penelitian ini adalah data sekunder yang mana data tersebut diperoleh langsung dari Pangkalan Data Perguruan Tinggi (PDPT) STMIK Amik Riau, data tersebut adalah nilai mahasiswa konsentrasi bisnis dari semester 1-5, adapun sampel data tersebut adalah sebagai berikut:

Tabel 1. Data Penelitian

\begin{tabular}{|c|c|c|c|c|c|c|c|c|c|c|}
\hline No & MATAKULIAF & $\begin{array}{l}\text { Logika dan } \\
\text { Algorithma }\end{array}$ & OOP & $\begin{array}{l}\text { Dasar } \\
\text { Pemrograman }\end{array}$ & $\begin{array}{l}\text { Analisa } \\
\text { S Sistem }\end{array}$ & $\begin{array}{l}\text { Perancangan } \\
\text { Sistem }\end{array}$ & $\begin{array}{l}\text { n Pemrograma } \\
\text { n Mobile } 1 .\end{array}$ & $\begin{array}{l}\text { a Rekayasa } \\
\text { Interface }\end{array}$ & $\begin{array}{l}\text { Pemrograma } \\
\mathrm{n} \text { Web. }\end{array}$ & $\begin{array}{l}\text { Rekayasa } \\
\text { Perangkat } \\
\text { Lunak }\end{array}$ \\
\hline 1 & $\begin{array}{l}\text { ALFARABY } \\
\text { INDRA } \\
\end{array}$ & 86,1 & 85,3 & 93 & 90 & 92 & 86,5 & 78 & 87,9 & 87 \\
\hline 2 & $\begin{array}{l}\begin{array}{l}\text { BAMBANG } \\
\text { PERMADI }\end{array} \\
\end{array}$ & 86,2 & 61 & 72 & 86 & 83 & 76,6 & 72 & 81,5 & 84 \\
\hline 3 & $\begin{array}{l}\text { DEDY } \\
\text { ALFIKRI }\end{array}$ & 50,1 & 64,9 & 72,8 & 73 & 79 & 61 & 58 & 78,8 & 79 \\
\hline 4 & $\begin{array}{l}\text { FIKA } \\
\text { FELANDA } \\
\text { ARDELAA }\end{array}$ & 76,3 & 7,8 & 73 & 87 & 85 & 76 & 64 & 77,3 & 82 \\
\hline 5 & $\begin{array}{l}\text { INTAN URFA. } \\
\text { KS }\end{array}$ & 86 & 73,8 & 73,9 & 95 & 89 & 76,5 & 81 & 81,5 & 86 \\
\hline 6 & $\begin{array}{l}\text { ISHAD } \\
\text { NASOHA }\end{array}$ & 82,4 & 78 & 74 & 71,2 & 81 & 76,3 & 56 & 65 & 87,7 \\
\hline 7 & $\begin{array}{l}\text { KADEK } \\
\text { MIRNAWATI } \\
\end{array}$ & 94,1 & ,8, & 5,8 & 87 & 85 & 76,5 & 90,5 & 80 & 86 \\
\hline 8 & $\begin{array}{l}\text { LULIK } \\
\text { ABDUL LATIF }\end{array}$ & 95.7 & 67.8 & 76.4 & 76 & 83 & 74 & 72 & 80.3 & 84 \\
\hline 9 & $\begin{array}{l}\text { M. YUSUF } \\
\text { RIVAI }\end{array}$ & 66,1 & 63,3 & 66,5 & 74,3 & 84 & 76,2 & 63 & 67 & 73,6 \\
\hline 10 & $\begin{array}{l}\text { NECI } \\
\text { PURWANDA }\end{array}$ & 87 & 87,5 & 75,8 & 89 & 82 & 79,3 & 84,5 & 77 & 88 \\
\hline
\end{tabular}

\section{Algoritma Penelitian}

Algoritma yang digunakan pada penelitian ini adalah Apriori karena Algoritma Apriori adalah algoritma yang banyak digunakan untuk menemukan pola frekuensi tinggi. Pola frekuensi tinggi adalah pola-pola item di dalam suatu database yang 
memiliki frekuensi atau support di atas ambang batas tertentu yang disebut dengan istilah minimum support.

\section{Pengujian Penelitian}

Aplikasi yang akan digunakan untuk melakukan pengujian adalah Rapid Miner karena Rapid Miner menyediakan prosedur data mining dan machine learning, di dalamnya termasuk: ETL (extraction, transformation, loading),data preprocessing, visualisasi, modelling dan evaluasi. Proses data mining tersusun atas operator-operator yang nestable, dideskripsikan dengan XML, dan dibuat dengan GUI..

\section{HASIL DAN PEMBAHASAN}

Berdasarkan data yang diperoleh maka dibuat sebuah kesimpulan bahwa nilai yang digunakan adalah setiap nilai matakuliah besar sama dengan 76 (76 keatas) dan mahasiswa tersebut adalah mahasiswa aktif dari semester 1 sampai dengan semester 5. Sehingga diperoleh data sebagai berikut ini:

Tabel 2. Format Tabular Data Nilai Mahasiswa

\begin{tabular}{|c|c|c|c|c|c|c|c|c|c|c|}
\hline No & MATAKULIAF & $\begin{array}{l}\text { ogika dan } \\
\text { goorithma }\end{array}$ & OOP & $\begin{array}{l}\text { Dasar } \\
\text { Pemrograman }\end{array}$ & $\begin{array}{l}\text { Analisa } \\
\text { Sistem }\end{array}$ & $\begin{array}{l}\text { Perancangan } \\
\text { Sistem }\end{array}$ & $\begin{array}{l}\text { Penrograma } \\
\text { n Mobile } 1 .\end{array}$ & $\begin{array}{l}\text { Rekayasa } \\
\text { Interface }\end{array}$ & $\begin{array}{l}\text { Pemrograma } \\
\mathrm{n} \text { Web. }\end{array}$ & $\begin{array}{l}\text { Rekayasa } \\
\text { Perangkat } \\
\text { Lunak } \\
\end{array}$ \\
\hline 1 & $\begin{array}{l}\text { ALFARABY } \\
\text { INDRA }\end{array}$ & 86,1 & 85,3 & 93 & 90 & 92 & 86,5 & 78 & 87,9 & 87 \\
\hline 2 & $\begin{array}{l}\text { BAMBANG } \\
\text { PERMADI }\end{array}$ & 86,2 & & & 86 & 83 & 76,6 & & 81,5 & 84 \\
\hline 3 & $\begin{array}{l}\text { DEDY } \\
\text { ALFIKRI }\end{array}$ & & & & & 79 & & & 78,8 & 79 \\
\hline 4 & $\begin{array}{l}\text { FIKA } \\
\text { FELANDA } \\
\text { ARDELIA }\end{array}$ & 76,3 & 87,8 & & 87 & 85 & 76 & & 77,3 & 82 \\
\hline 5 & $\begin{array}{l}\text { INTAN URFA. } \\
\text { KS }\end{array}$ & 86 & & & 95 & 89 & 76,5 & 81 & 81,5 & 86 \\
\hline 6 & $\begin{array}{l}\text { ISHAD } \\
\text { NASOHA }\end{array}$ & 82,4 & 78 & & & 81 & 76,3 & & & 87,7 \\
\hline 7 & $\begin{array}{l}\text { KADEK } \\
\text { MIRNAWATI }\end{array}$ & 94,1 & & & 87 & 85 & 76,5 & 90,5 & 80 & 86 \\
\hline 8 & $\begin{array}{l}\text { LULIK } \\
\text { ABDUL LATIF }\end{array}$ & 95.7 & & 76.4 & 76 & 83 & & & 80.3 & 84 \\
\hline 9 & $\begin{array}{l}\text { M. YUSUF } \\
\text { RIVAI }\end{array}$ & & & & & 84 & 76,2 & & & \\
\hline 10 & $\begin{array}{l}\text { NECI } \\
\text { PURWANDA }\end{array}$ & 87 & 87,5 & & 89 & 82 & 79,3 & 84,5 & 77 & 88 \\
\hline
\end{tabular}

Kemudian data pada Tabel 2 dikonversi kedalam bentuk nilai 0 dan 1 . Dimana, nilai yang bernilai 0 adalah cell yang kosong atau tidak memenuhi syarat, dan cell yang berisi diberi nilai 1 .

Langkah selanjutnya adalah proses pembentukan $\mathrm{C} 1$ atau disebut dengan 1 itemset dengan jumlah minimum support $=70 \%$.
Tabel 3. Format Tabular Dalam Bentuk 0 dan 1

\begin{tabular}{|c|c|c|c|c|c|c|c|c|c|c|}
\hline No & MATAKULIAH & $\begin{array}{l}\text { Logika dan } \\
\text { Algorithma }\end{array}$ & OOP & $\begin{array}{c}\text { Dasar } \\
\text { Pemrograman }\end{array}$ & $\begin{array}{l}\text { Analisa } \\
\text { Sistem }\end{array}$ & $\begin{array}{c}\text { Perancangar } \\
\text { Sistem }\end{array}$ & $\begin{array}{l}\text { neemrograma } \\
\text { n Mobile } 1 .\end{array}$ & $\begin{array}{l}\text { Rekayasa } \\
\text { Interface }\end{array}$ & $\begin{array}{c}\text { Pemrograma } \\
\text { n Web. }\end{array}$ & $\begin{array}{c}\text { Rekayasa } \\
\text { Perangkat } \\
\text { Lunak }\end{array}$ \\
\hline 1 & $\begin{array}{l}\text { ALFARABY } \\
\text { INDRA }\end{array}$ & 1 & 1 & 1 & 1 & 1 & 1 & 1 & 1 & 1 \\
\hline 2 & $\begin{array}{l}\text { BAMBANG } \\
\text { PERMADI }\end{array}$ & 1 & 0 & 0 & 1 & 1 & 1 & 0 & 1 & 1 \\
\hline 3 & DEDY ALFIKRI & 0 & 0 & 0 & 0 & 1 & 0 & 0 & 1 & 1 \\
\hline 4 & $\begin{array}{l}\text { FIKA FELANDA } \\
\text { ARDELIA }\end{array}$ & 1 & 1 & 0 & 1 & 1 & 1 & 0 & 1 & 1 \\
\hline 5 & $\begin{array}{l}\text { INTANURFA. } \\
\text { KS }\end{array}$ & 1 & 0 & 0 & 1 & 1 & 1 & 1 & 1 & 1 \\
\hline 6 & ISHAD NASOHA & 1 & 1 & 0 & 0 & 1 & 1 & 0 & 0 & 1 \\
\hline 7 & $\begin{array}{l}\text { KADEK } \\
\text { MIRNAWATI } \\
\end{array}$ & 1 & 0 & 0 & 1 & 1 & 1 & 1 & 1 & 1 \\
\hline 8 & $\begin{array}{l}\text { LULIK ABDUL } \\
\text { LATIF } \\
\end{array}$ & 1 & 0 & 1 & 1 & 1 & 0 & 0 & 1 & 1 \\
\hline 9 & M. YUSUF RIVAI & 0 & 0 & 0 & 0 & 1 & 1 & 0 & 0 & 0 \\
\hline 10 & $\begin{array}{l}\text { NECI } \\
\text { PURWANDA } \\
\end{array}$ & 1 & 1 & 0 & 1 & 1 & 1 & 1 & 1 & 1 \\
\hline
\end{tabular}

Tabel 4. Kandidat 1 Item Set dan Jumlah Item

\begin{tabular}{cll}
\hline NO & \multicolumn{1}{c}{ ITEM } & TRANSAKSI \\
\hline 1 & Logika dan Algorithma & 8 \\
\hline 2 & OOP & 4 \\
\hline 3 & Dasar Pemrograman & 2 \\
\hline 4 & Analisa Sistem & 7 \\
\hline 5 & Perancangan Sistem & 10 \\
\hline 7 & Pemrograman Mobile 1. & 8 \\
\hline 8 & Pemrograman Web. & 4 \\
\hline 9 & Rekayasa Perangkat Lunak & 9 \\
\hline
\end{tabular}

Kemudian pada Tabel 4 dilakukan penghitungan/ menjumlah banyak transaksi (baris) yang dihasilkan sehingga menghasilkan Kandidat 1 itemset seperti Tabel 5.

Tabel 5. Hasil Perhitungan Support Kandidat 1 Itemset

\begin{tabular}{llccc}
\hline NO & \multirow{2}{*}{ ITEM } & TRANSAKSI & SUPPORT \\
\hline 1 & Logika dan Algorithma & 8 & $(8 / 10) \times 100 \%=$ & $80 \%$ \\
\hline 2 & OOP & 4 & $(4 / 10) \times 100 \%=$ & $40 \%$ \\
\hline 3 & Dasar Pemrograman & 2 & $(2 / 10) \times 100 \%=$ & $20 \%$ \\
\hline 4 & Analisa Sistem & 7 & $(7 / 10) \times 100 \%=$ & $70 \%$ \\
\hline 5 & Perancangan Sistem & 10 & $(10 / 10) \times 100 \%=$ & $100 \%$ \\
\hline 6 & Pemrograman Mobile 1. & 8 & $(8 / 10) \times 100 \%=$ & $80 \%$ \\
\hline 7 & Rekayasa Interface & 4 & $(4 / 10) \times 100 \%=$ & $40 \%$ \\
\hline 8 & Pemrograman Web. & 8 & $(8 / 10) \times 100 \%=$ & $80 \%$ \\
\hline 9 & Rekayasa Perangkat Lunak & 9 & $(9 / 10) \times 100 \%=$ & $90 \%$ \\
\hline
\end{tabular}


Selanjutnya dari nilai transaksi yang dihasilkan kemudian mencari nilai support dengan rumus :

Support $(\mathrm{A})=$ Jumlah transaksi mengandung A Total Transaksi

Dengan 1 item set, nilai support besar sama dengan $70 \%$ dihasilkan 6 rule sebagai berikut:

Tabel 6. Hasil 1 Item set Frekuent

\begin{tabular}{llcc}
\hline NO & \multicolumn{1}{c}{ ITEM } & TRANSAKSI & SUPPORT \\
\hline 1 & Logika dan Algorithma & 8 & $80 \%$ \\
\hline 2 & Analisa Sistem & 7 & $70 \%$ \\
\hline 3 & Perancangan Sistem & 10 & $100 \%$ \\
\hline 4 & Pemrograman Mobile 1 & 8 & $80 \%$ \\
\hline 5 & Pemrograman Web & 8 & $80 \%$ \\
\hline 6 & Rekayasa Perangkat Lunak & 9 & $90 \%$ \\
\hline
\end{tabular}

Selanjutnya proses tersebut diulang-ulang hingga mendapatkan 1 rule yaitu pada item set ke 5 :

Tabel 7. Hasil 5 Itemset Frekuent

\begin{tabular}{|c|c|c|c|c|}
\hline No & ITEM & TRANSAKSI & SUPPORT & \\
\hline 1 & $\begin{array}{l}\text { Logika dan Algorithma, Analisa } \\
\text { Sistem, Perancangan Sistem, } \\
\text { Pemrograman Web, Rekayasa } \\
\text { Perangkat Lunak }\end{array}$ & 7 & $(7 / 10) \times 100 \%=$ & $70 \%$ \\
\hline
\end{tabular}

Tabel 8. Hasil Keputusan

\begin{tabular}{llcccrc}
\hline NO & MATAKULIAH & $\begin{array}{l}\text { Logika dan } \\
\text { Algorithma }\end{array}$ & $\begin{array}{l}\text { Analisa } \\
\text { Sistem }\end{array}$ & \multicolumn{1}{l}{$\begin{array}{l}\text { Pemrograman } \\
\text { Web. }\end{array}$} & $\begin{array}{l}\text { Rekayasa } \\
\text { Perangkat } \\
\text { Lunak }\end{array}$ & Keterangan \\
\hline $\mathbf{1}$ & $\begin{array}{l}\text { ALFARABY } \\
\text { INDRA }\end{array}$ & 86,1 & 90 & 87,9 & 87 & Memenuhi \\
\hline $\mathbf{2}$ & $\begin{array}{l}\text { BAMBANG } \\
\text { PERMADI }\end{array}$ & 86,2 & 86 & 81,5 & 84 & Memenuhi \\
\hline $\mathbf{3}$ & DEDY ALFIKRI & 50,1 & 73 & 78,8 & 79 & Tidak \\
\hline $\mathbf{4}$ & $\begin{array}{l}\text { FIKA FELANDA } \\
\text { ARDELIA }\end{array}$ & 76,3 & 87 & 77,3 & 82 & Memenuhi \\
\hline $\mathbf{5}$ & $\begin{array}{l}\text { INTAN URFA. } \\
\text { KS }\end{array}$ & 86 & 95 & 81,5 & 86 & Memenuhi \\
\hline $\mathbf{6}$ & ISHAD NASOHA & 82,4 & 71,2 & 65 & 87,7 & Tidak \\
\hline $\mathbf{7}$ & $\begin{array}{l}\text { KADEK } \\
\text { MIRNAWATI }\end{array}$ & 94,1 & 87 & 80 & 86 & Memenuhi \\
\hline $\mathbf{8}$ & $\begin{array}{l}\text { LULIK ABDUL } \\
\text { LATIF }\end{array}$ & 95.7 & 76 & 80.3 & 84 & Memenuhi \\
\hline $\mathbf{9}$ & M. YUSUF RIVAI & 66,1 & 74,3 & 67 & 73,6 & Tidak \\
\hline $\mathbf{1 0}$ & $\begin{array}{l}\text { NECI } \\
\text { PURWANDA }\end{array}$ & 87 & 89 & 77 & 88 & Memenuhi \\
\hline & & & & & & \\
\hline
\end{tabular}

Setelah didapatkan 1 rule terakhir pada Tabel 7 maka dapat diperoleh keterangan seperti Tabel 8, disimpulkan bahwa mahasiswa yang mendapatkan nilai besar sama dengan 76 untuk nilai matakuliah: Logika dan Algorithma, Analisa Sistem,
Perancangan Sistem, Pemrograman Web dan Rekayasa Perangkat Lunak dianggap memenuhi untuk memilih konsentrasi bisnis.

\section{Pengujian Menggunakan Rapid Miner}

Setelah hitungan manual tercapai, maka selanjutnya dilakukan pengujian menggunakan Tool Rapid Miner, hasil pengujian menyatakan bahwa rule yang didapat benar adanya. Pengujian dilakukan untuk mengukur kecocokan antara data uji dengan hasil diaplikasi, aplikasi yang digunakan yaitu Tool Rapid Miner yang dianggap cocok dengan kebutuhan penelitian ini, sebab setiap rule yang terbentuk dapat dibuktikan valid atau tidaknya dengan aplikasi ini.

\section{Tampilan awal}

Tampilan awal Rapid Miner sebelum pengujian dilakukan.

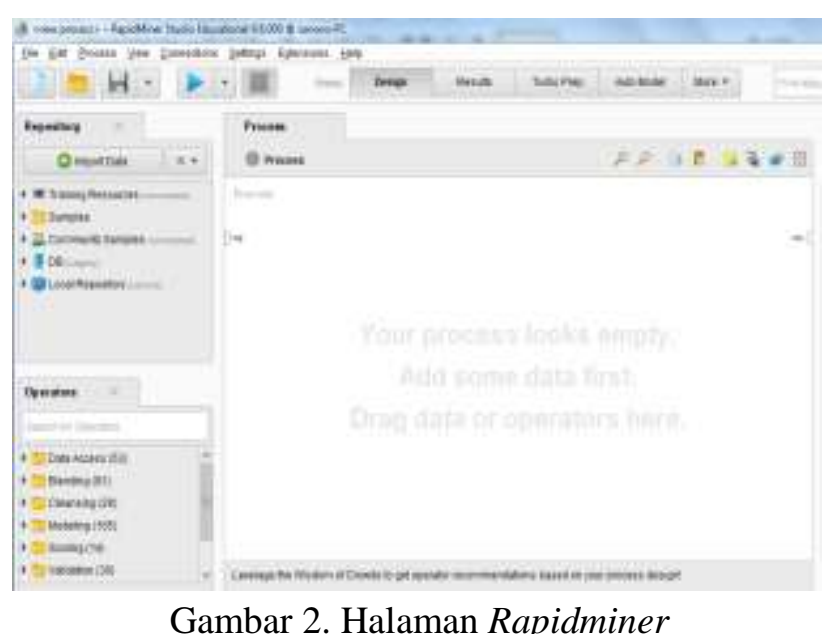

\section{Import Data}

Pada tahap ini dilakukan import data untuk memulai proses pengujian.

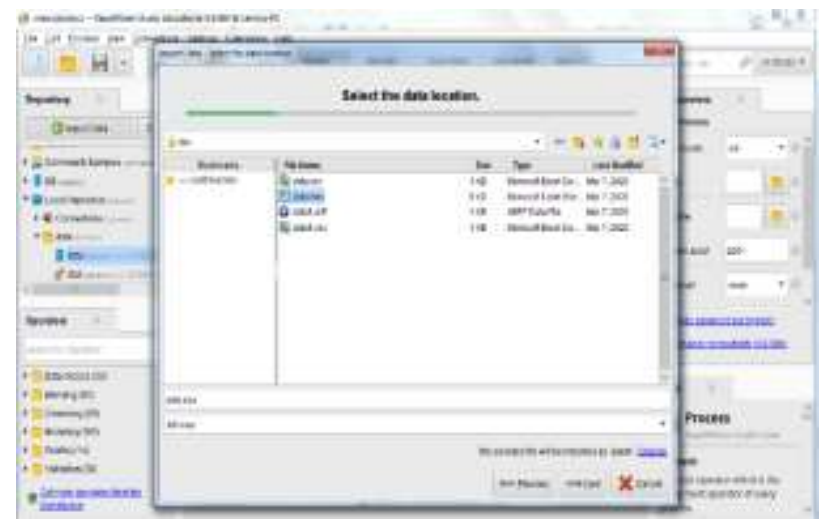

Gambar 3. Import Data Pengujian 


\section{Data Pengujian yang telah diimport}

Data yang digunakan dalam Rapid miner adalah data yang telah dikonversi dalam bentuk 0 dan 1 , yaitu sebagai berikut:

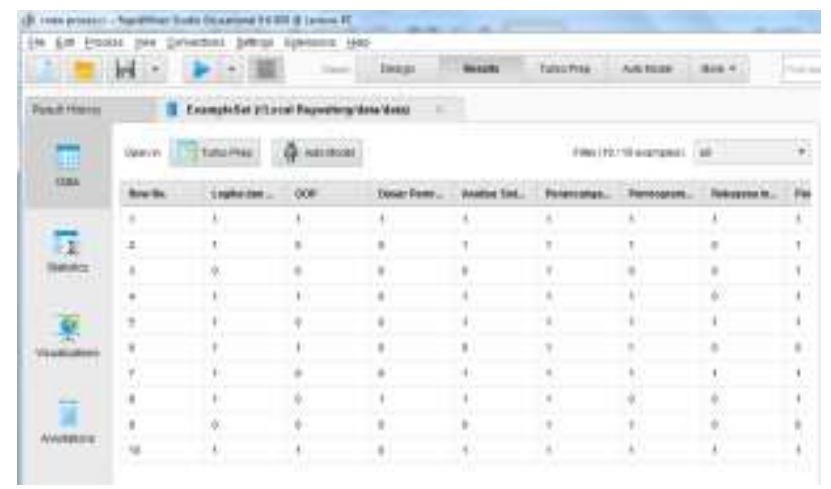

Gambar 4. Data Pengujian Rapid Miner yang telah diimport

\section{Asosiasi Rule}

Langkah selanjutnya adalah mendesain asosiasi rule, adapun asossiasi rule yang digunakan adalah sebagai berikut :

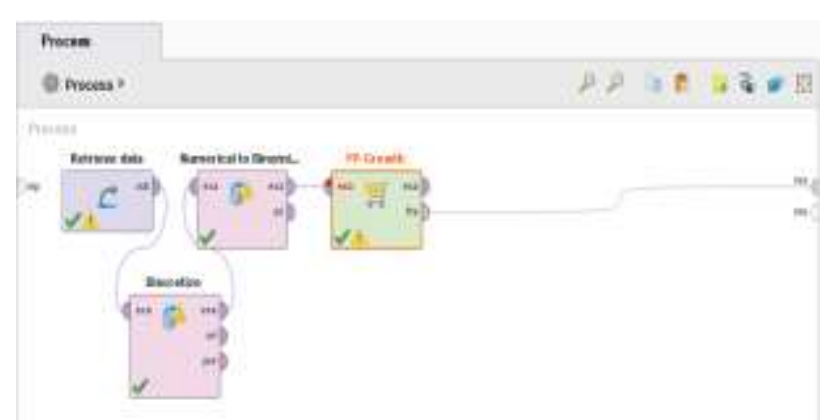

Gambar 5. Assosiasi Rule

\section{Eksekusi}

Setelah menentukan asosiasi rule, langkah selanjutnya adalah melakukan eksekusi, dan didapat hasil sebagai berikut :

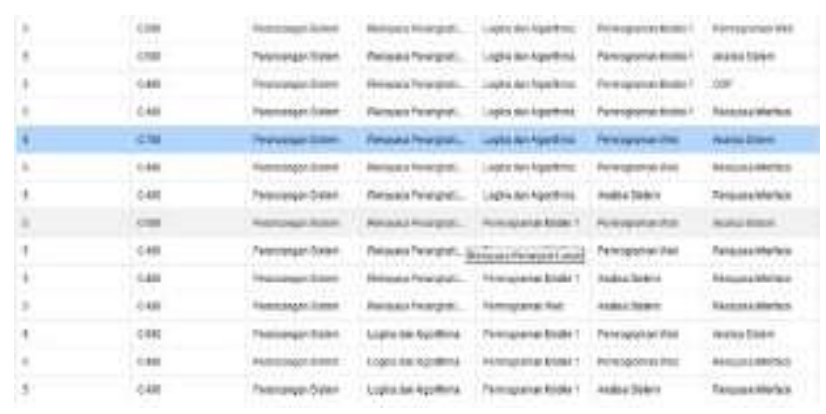

Gambar 5. Eksekusi

\section{KESIMPULAN}

Berdasarkan hasil implementasi dan uji coba yang telah dilakukan dapat disimpulkan bahwa:

1. Data awal adalah data mahasiswa konsentrasi bisnis angkatan 2016 yang diambil dari 9 matakuliah dan pada akhirnya didapatkan 5 matakuliah.

2. Hasil perhitungan manual dengan hasil pembuktian pada aplikasi, didapatkan hasil yang sama.

3. Menggunakan nilai minimum support $70 \%$ menghasilkan rule dengan 5 item set yaitu mata kuliah logika dan algorithma, analisa sistem, perancangan sistem, pemrograman web dan rekayasa perangkat lunak.

4. Rule yang dihasilkan dapat menjadi panduan bagi mahasiswa dalam memilih konsentrasi bisnis.

5. Setelah melalui proses 5 item set dapat ditemukan mahasiswa yang memenuhi untuk masuk kedalam konsentrasi bisnis maupun mahasiswa yang sebetulnya tidak memenuhi untuk masuk kedalam konsentrasi bisnis.

6. Hasil penelitian ini dapat dijadikan sebagai penunjang proses belajar khusus pada mata kuliah Data Mining.

\section{DAFTAR PUSTAKA}

Turban , Efraim \& Aronson, Jay E. 2001. Decision Support Systems and Intelligent Systems. $6^{\text {th }}$ edition. Prentice Hall: Upper Saddle River, NJ

HAN, Jiawei; PEI, Jian; KAMBER, Micheline. Data Mining: Concepts And Techniques. Elsevier, 2011.

Larose, Daniel T. 2005. Discovering Knowledge in Data : An Introduction to Data Mining. John Willey \& Sons, Inc.

Ayyad, Usama. 1996. Advances in Knowledge Discovery and Data Mining. MIT Press.

Kusrini and Emha Hermawati, Data Mining, 1st ed. Yogyakarta, Indonesia: Putri Christian, 2013.

Elsa Widiati and Kania Evita Dewi, "Implementasi Association Rule Terhadap Penyusunan Layout Makanan dan Penentuan Paket Makanan Hemat di RM Roso Echo dengan Algoritma Apriori," Jurnal Ilmiah Komputer dan Informatika (KOM PUTA), vol. 3, pp. 96101, Oktober 2014. 
Turban, E, 2005, Decision Support Systems and Intelligent Systems Edisi Bahasa Indonesia Jilid 1. Andi: Yogyakarta.

Wirdah. (2016). Penggunaan Algorithma Apriori Data Mining untuk Mengetahui Tingkat Kesetiaan Konsumen (Brand Loyality) terhadap Merek Kenderaan Bermotor (Studi Kasus Dealer Honda Rumbai )", Jurnal Teknologi Informasi \& Komunikasi Digital Zone, Volume 7, Nomor 1, Februari 2016: 44-52.

Ependi, U., \& Putra, A. (2019). Solusi prediksi persediaan barang dengan menggunakan algoritma apriori (studi kasus: regional part depo auto 2000 Palembang). Jurnal Edukasi dan Penelitian Informatika (JEPIN), 5(2), 139-145. 